\title{
The Level of ROS and DNA Damage Mediate with the Type of Cell Death, Senescence or Apoptosis
}

\author{
Takafumi Inoue and Norio Wake \\ Department of Obstetrics and Gynecology, \\ Kyushu University, Fukuoka, \\ Japan
}

\section{Introduction}

Cell senescence, originally defined as the proliferative arrest that occurs in normal cells after a limited number of cell divisions, is now more broadly regarded as a general biological program of terminal growth arrest. Replicative senescence of cells due to telomeric changes exhibits similar features with those seen in DNA damage (Vaziri et al., 1997; von Zglinicki, 2001). Therefore, DNA damage is expected to induce rapid cell growth arrest, which would be phenotypically indistinguishable from replicative senescence (Di Leonardo et al., 1994). This type of accelerated senescence that does not involve telomere shortening is triggered in normal cells by the expression of supraphysiological mitogenic signals (Orr et al., 1994). Not only normal cells, but also cancer cells can be induced readily to undergo senescence by genetic manipulation or by treatment with chemotherapeutic agents, radiation, or differentiating agents.

Reactive oxygen species (ROS), which are byproducts of normal cellular oxidative processes, are involved in senescence (Chen et al., 1998). Senescent cells have higher levels of ROS than normal cells (Hagen et al., 1997), and oxidative stress caused by sublethal doses of $\mathrm{H}_{2} \mathrm{O}_{2}$ or hyperoxia can force human fibroblasts to arrest in a manner similar to senescence (Dumount et al., 2000). Additionally, both oncogenic Ras and p53 induce senescence in association with increased intracellular ROS (Lee et al., 1999; Macip et al., 2003). p53 induces the accumulation of ROS presumably through a transcriptional influence on pro-oxidant genes (Polyak et al., 1997). Up-regulation of p21 also causes increased ROS levels in both normal and cancer cells (Macip et al., 2002), although the molecular mechanism remains unknown.

Recent evidence has suggested that p21 mediates apoptosis in a p53-independent manner (Roninson, 2003; Hsu et al., 1999), although its role in this apoptotic pathway remains controversial. In view of the possible roles played by ROS in both senescence and apoptosis, and the capacity of p21 to elevate ROS levels, we investigated the involvement of ROS in p21-induced cell death. Additionally, we studied how the status of p21 expression modulated ROS levels to achieve alternative cell fates. 


\section{Exogenous p21 protein induces senescence and apoptosis induced by p21 mediated through p53}

We generated the recombinant adenovirus vector contained either the full-length p21 (Adp21). An adenovirus containing an empty vector (mock) was used as a control. We transferred these constructs into two cancer cell lines (LoVo, and HCT116) using an adenovirus infection system. The cell lines were initially selected based on their susceptibility $(>80 \%)$ to adenovirus. The expression of p21 protein corresponding to the transfected vector was demonstrated by immunoblots (data not shown).

Infection of these cancer cell lines with 20MOI Ad-p21 resulted in growth arrest, which became irreversible after four days. This permanent growth arrest was accompanied by the presence of a senescence-specific marker, SA- $\beta$-gal positivity, as well as morphological changes such as a dramatic increase in cell size, and enlarged and prominent nuclei.

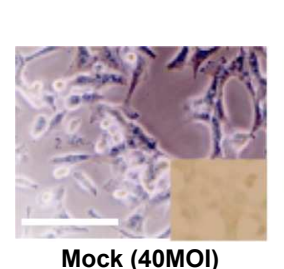

Mock (40MOI)

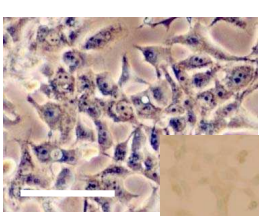

Mock (40MOI)

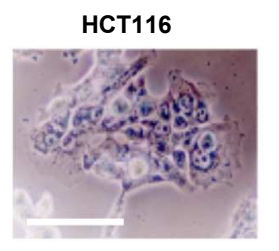

Ad-p21 (20MOI)

LoVo

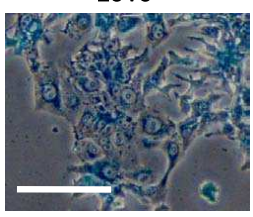

Ad-p21F(20MOI)

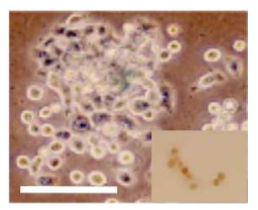

Ad-p21 (40MOI)

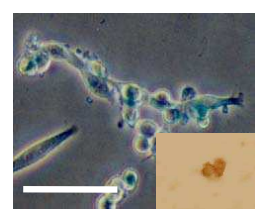

Ad-p21 (40MOI)

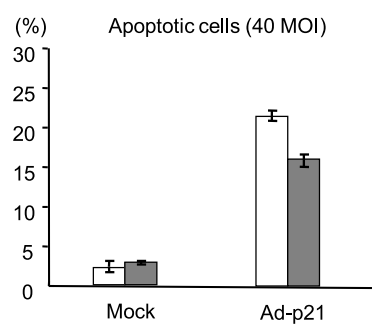

口 LoVo
HCT116

Fig. 1. Induction of senescence and apoptosis by p21 overexpression.

When LoVo and HCT116 cells were transfected with 20 MOI Ad-p21, cells were enlarged, flattened and had increased SA- $\beta$-gal positivity. At 40 MOI (LoVo and HCT116), cells were detached from the plate and floating. The small panel on the lower right for $40 \mathrm{MOI}$ shows positive cells with the TUNEL assay. Mock transfected cells showed no change in morphology and were not positive for the TUNEL assays. The populations of apoptotic cells in LoVo and HCT116 infected with 40 MOI Ad-p21 after infection of 48 hrs are shown in right graph as indicated by the significant increased of sub G1 fraction. Data represent the average of three independent experiments and standards deviations are indicated by error bars. Bar $=10 \mu \mathrm{m}$ 
The apoptosis of cancer cells following DNA damage is p53-dependent and yet p21independent (Waldman et al., 1996; Deng et al., 1995). However, due to differences in the experimental conditions for investigation the effects, contradictory conclusions have been drawn regarding the relationship between p21 and the induction of apoptosis (Tsao et al., 1999; Kagawa et al., 1999). In order to investigate the basis for the striking differences in the biologic responses to p21 expression, we measured the kinetics of p21 protein increase, as well as its expression levels following Ad-p21 infection by increasing MOI of the viral vector. Whereas $20 \mathrm{MOI}$ Ad-p21 infection resulted in elongated, growth-arrested cells showing the morphological features of senescence, cells infected with 40 MOI Ad-p21 became rounded, contracted, and lost their ability to adhere to the plate with Apo-taq positive staining (Fig. 1). We used flow cytometry to measure the DNA contents of cancer cell lines following treatment Ad-p21. In LoVo and HCT116 cells, a hypoploid peak corresponding to a subG1 population had increased following infection with Ad-p21 (40 MOI) (data not shown). These results are characteristic of apoptosis.

\section{The fate of cancer cells as a result of ROS generated by overexpressed p21 from adenoviral transfection}

To investigate the roles of ROS in the senescent or apoptotic cell fates triggered by p21 expression in LoVo and HCT116 cells, we measured ROS levels with the fluorescent probe APF (Setsukinai et al., 2003), a marker of changes in the general accumulation of cellular oxidants. FACS analysis of APF-stained LoVo and HCT116 cells revealed a progressive increase in ROS levels following 20 MOI Ad-p21 infection. After three days of infection, when senescent morphological changes were first observed, the ROS levels in the cells were increased more than 2-fold. We next examined whether ROS levels were involved in the decision between senescence and apoptosis in LoVo and HTC116 cells. Both cells infected with 40 MOI Ad-p21 exhibited much higher ROS levels (4-fold) than did the cells infected with 20 MOI Ad-p21 (2-2.5 fold) (Fig. 2a).

We then established whether different cell fate outcomes were due to the levels of induced ROS and p21 protein. We investigated whether the antioxidant N-acetyl-L-cysteine (NAC), could protect cells from senescent phenotypes induced by 20 MOI Ad-p21 infection or the apoptotic phenotype by 40 MOI Ad-p21 infection. Both LoVo and HCT116 cells that harbored the wild type p53 gene were infected with 20MOI Ad-p21 were cultured in the presence of $10 \mathrm{mM}$ NAC for three days. Ad-p21 markedly induced SA- $\beta$-gal positive cells in the absence of NAC, and cultivation in the presence of NAC significantly suppressed the appearance of SA- $\beta$-gal-positive cells (Fig. 2 b). Similarly, cultivation of LoVo and HCT116 cells in the presence of NAC for 3 days markedly inhibited apoptosis in response to $40 \mathrm{MOI}$ Ad-p21 infection (Fig. 2c), thus suggesting that the induction of both senescence and apoptosis by $\mathrm{p} 21$ occurs via the generation of ROS.

\section{Endogenous p21 protein up-regulation by sodium butyrate $(\mathrm{NaB})$ induces cell death in a colon cancer cell line, HCT116}

Next, we investigated whether up-regulation of endogenous p21 protein has an effect similar to that of Ad-p21 infection. We have previously demonstrated that $\mathrm{NaB}$ induced p21 expression, resulting in growth arrest and cell death in gynecologic cancer cells. (8) 


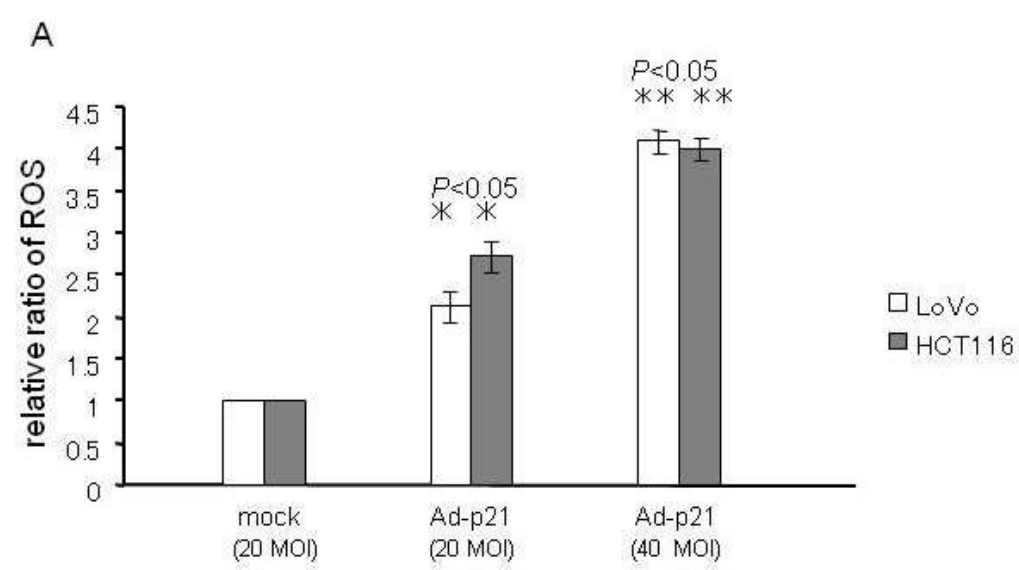

B

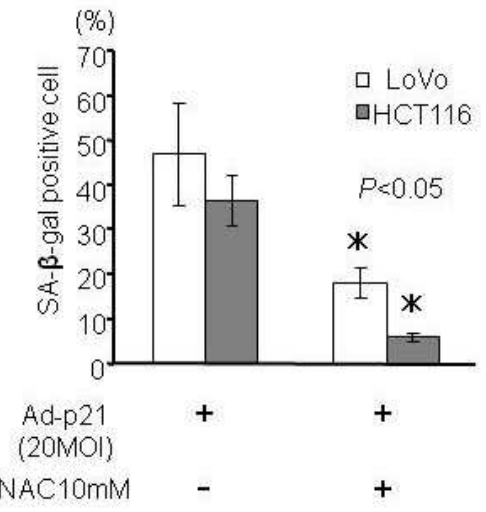

C

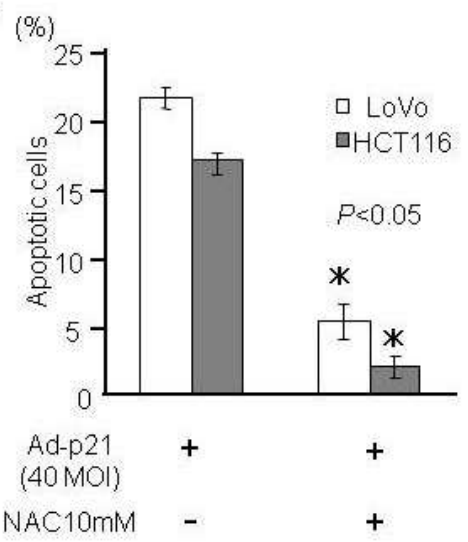

Fig. 2. ROS levels in cancer cell lines in response to p21 expression levels.

(a) ROS levels were evaluated by FACS analysis after staining LoVo and HCT116 cells with the fluorescent probe APF. Relative ratio of the geometric mean that is the average of the logarithm of the linear value for events expressed as the anti log in Ad-p21 (20 MOI or 40 MOI) infected cells as compared to the control (20MOI). Generated ROS levels were significantly higher in the cancer cells infected with 20 MOI Ad-p21 than those in control infected cells. ${ }^{*} P<0.05$ In LoVo and HCT116 cells, generated ROS levels were significantly higher in the cancer cells infected with 40 MOI Ad-p21 than those in $20 \mathrm{MOI}$. ${ }^{* *} P<0.05$ Apoptosis was induced in the former and senescence in the latter.

(b) Senescence induced by p21-overexpression was inhibited by NAC (ROS scavenger). LoVo and HCT116 cells were cultured in $10 \mathrm{mM}$ NAC and were infected with $20 \mathrm{MOI}$ Adp21. The ratio of SA- $\beta$-gal positive cells after $74 \mathrm{hrs}$ of the infection was significantly decreased in the presence of NAC. Results represent mean values of three experiments, and error bar shows the standard deviation.

(c) Induction of apoptosis with 40 MOI Ad-p21 was also inhibited by the addition of NAC in LoVo and HCT116 cells, as indicated by the significant decrease of sub G1 fraction. Results represent mean values of three experiments, and error bars shows the standard deviation. 
To evaluate the induction of senescence in HCT116 cells, we analyzed the cell cycle alteration and SA- $\beta$ gal staining in response to $\mathrm{NaB}$. We measured the DNA contents of cancer cell lines treated with varying concentrations of NaB by flow cytometry. In HCT116, treatment with 0.5 to $1.0 \mathrm{mM} \mathrm{NaB}$ resulted in a decrease in the fraction of $\mathrm{S}$ phase $(21 \% \rightarrow 4 \%)$ and G1 phase cells $(57 \% \rightarrow 22 \%)$. Most cells accumulated in G2/M, suggesting arrest at the G2/M checkpoint. A hypoploid peak corresponding to the subG1 population was evident by flow cytometry following treatment with greater than $2.0 \mathrm{mM} \mathrm{NaB}$ (Fig. 3a). This population corresponded to cells undergoing apoptotic cell death.

\section{A. HCT116}

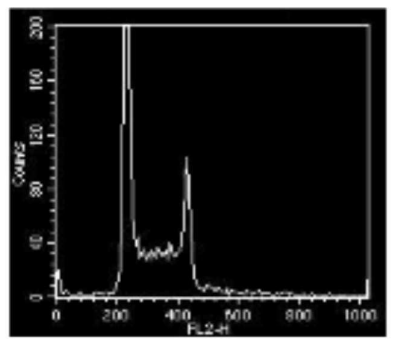

control

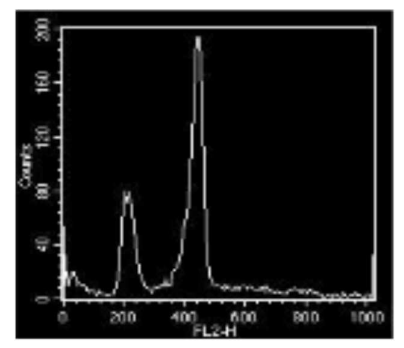

$\mathrm{NaB} 1.0 \mathrm{mM}$

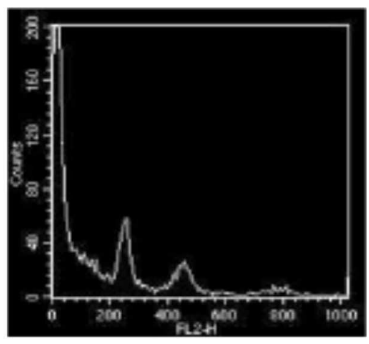

$\mathrm{NaB} 5.0 \mathrm{mM}$

B

\begin{abstract}
S phase $\quad 21.2 \%$ G2/M phase $15.6 \%$
\end{abstract}
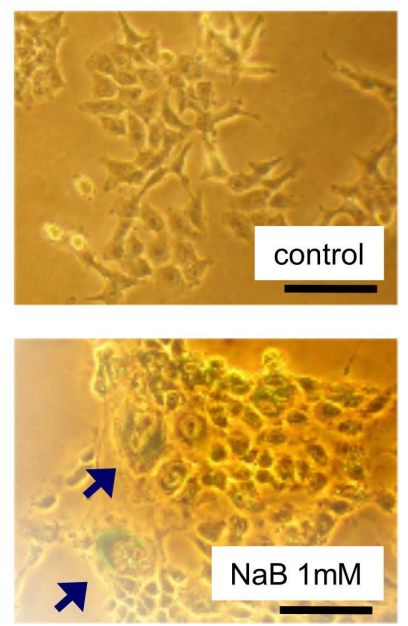

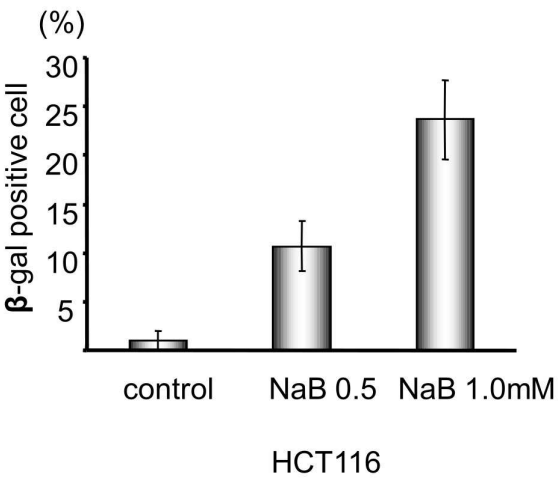

Fig. 3. (a) Effect of $\mathrm{NaB}$ on cell cycle analysis and the induction of cell death. DNA contents of HeLa and HCT116 cells with or without $\mathrm{NaB}$ for 24 hrs were analyzed by flow cytometry. $\mathrm{NaB}$ treatment reduced the percentage of cells in $\mathrm{S}$ phase and triggered the accumulation of cells in G2/M phase in HCT116 treated with of $1.0 \mathrm{mM} \mathrm{NaB}$.

(b) Treatment with $1.0 \mathrm{mM} \mathrm{NaB}$ induced morphological change in HCT116 cells that included enlargement and flattening as well as an increase in the number of SA- $\beta$-gal positive cells (arrows). Bar=10 $\mathrm{mm}$ 
Incubation of HCT116 cells with $1.0 \mathrm{mM} \mathrm{NaB}$ for five days resulted in morphologic changes. These changes included an enlarged, flattened shape, increased cytoplasmic to nuclear ratio and decreased cell density accompanied by SA- $\beta$-gal staining (Fig. 3b).

\section{Increased ROS levels in NaB-induced senescence and apoptosis of cancer cells}

To investigate the contribution of ROS to senescence or apoptosis of HCT116 cells triggered by the treatment with different concentrations of $\mathrm{NaB}$, we measured ROS levels as described above. FACS analysis of APF-stained cancer cell lines revealed a progressive increase in ROS levels following $\mathrm{NaB}$ treatment. The levels of ROS were increased following treatment both with $1 \mathrm{mM}$ of $\mathrm{NaB}$ (2-3 fold) that induced senescence in HCT116 cells and with $5 \mathrm{mM}$ of $\mathrm{NaB}$ (5-fold) that induced apoptosis compared with no treatment in HCT116 cells (Fig. $4 a)$. The ROS level in apoptotic cells induced by $\mathrm{NaB}$ was markedly higher than that in senescent cells.

To further establish whether different cell fate outcomes were due to the induced ROS level, we investigated the effect of the antioxidant N-acetyl-L-cysteine (NAC) on the senescent phenotype. HCT116 cells were treated with $0.5 \mathrm{mM} \mathrm{NaB}$ in the presence or absence of $5 \mathrm{mM}$ NAC for 5 days. The increase of cell numbers in the G2/M fraction following treatment with $0.5 \mathrm{mM} \mathrm{NaB}$ was abrogated by co-treatment with $5 \mathrm{mM}$ NAC (Fig. 4b). As shown in Fig. 4c, culture in the presence of NAC significantly suppressed the number of SA- $\beta$-gal-positive HCT116 cells $(23 \% \rightarrow 10 \%)$. This was accompanied by a decrease in ROS level, which suggested that the induction of senescence by $\mathrm{NaB}$ occurred via the generation of ROS. The treatment with NAC, however, could not prevent the apoptotic induction by higher concentrations of $\mathrm{NaB}$ in and HCT116 cells (data not shown), though the reason remained unknown.

\section{DNA damage response (DDR) signals mediate NaB-induced cancer cell death}

To clarify the association of NaB-induced cancer cell death with the DNA damage response, we next assayed for DDR signals including ATM and its downstream signals. One of the first processes initiated by DSB (double strand break) is massive phosphorylation of the tail of the histone variant H2AX (Redon et al., 2002). Foci of phosphorylated H2AX ( $\mathrm{HH} 2 \mathrm{AX})$ are rapidly formed at the DSB sites and are thought to be essential for further recruitment of damage response proteins. $\gamma \mathrm{H} 2 \mathrm{AX}$ is dependent on the ATM protein and other members of the ATM family. (31) To examine the effect of NaB on DDR signals-related proteins, we analyzed the changes of DSB-related proteins expression levels in response to $\mathrm{NaB}$ by immunoblotting. Incubation with 1-5 mM NaB for $48 \mathrm{hrs}$ resulted in the accumulation of $\gamma \mathrm{H} 2 \mathrm{AX}$ and ATM in HCT116 cells. The downstream proteins such as p53, phosphorylated p38 MAPK, and p21 were up-regulated by $1-5 \mathrm{mM}$ $\mathrm{NaB}$ after $48 \mathrm{hrs}$ of incubation (Fig. 5a). In HCT116 cells, the levels of the DSB marker $\gamma \mathrm{H} 2 \mathrm{AX}$ were enhanced about 20 times when apoptosis was induced by incubating with $2 \mathrm{mM} \mathrm{NaB}$ and about 3.6 times when senescence was induced by 0.5 to $1.0 \mathrm{mM} \mathrm{NaB}$ for 24 hrs compared with the control (Fig. 5b). 


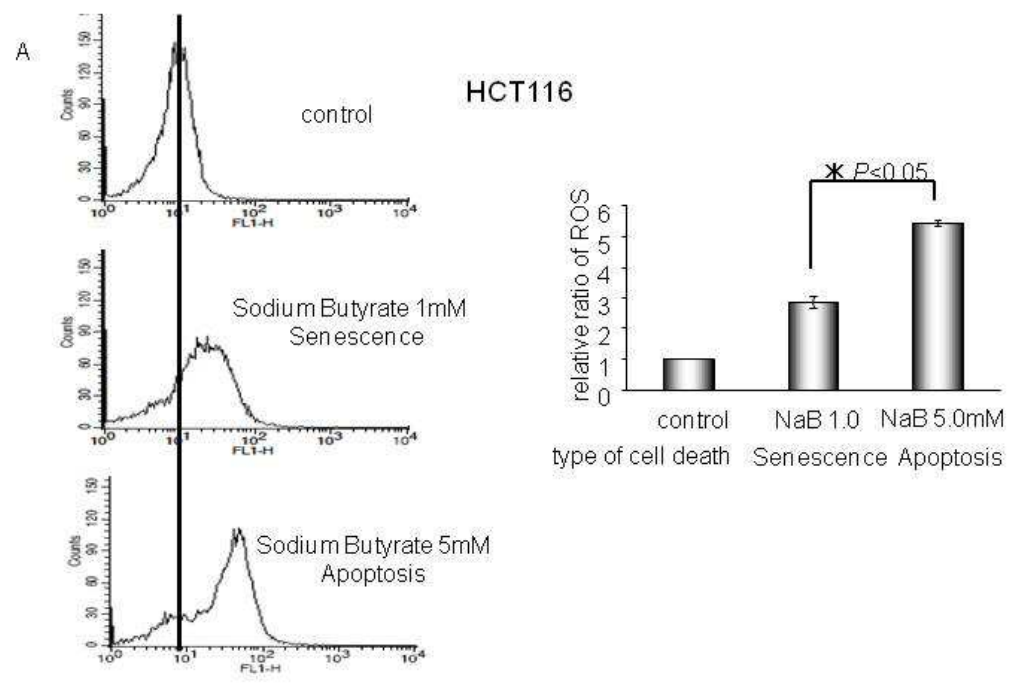

B. HCT116

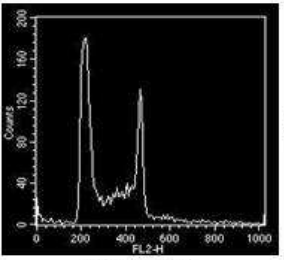

NAC $5 \mathrm{mM}$

G1 phase $\quad 51.7 \%$

Sphase $\quad 19.1 \%$

G2-M phase $21.8 \%$

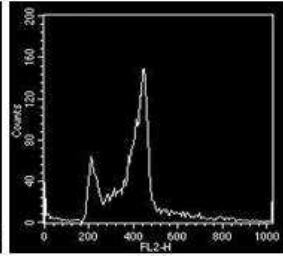

$\mathrm{NaB} 0.5 \mathrm{mM}$

G1 phase $\quad 16.0 \%$

Sphase $\quad 13.1 \%$

G2-M phase $57.5 \%$

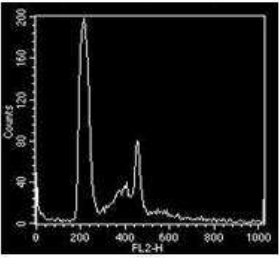

$\mathrm{NaB} 0.5 \mathrm{mM}+\mathrm{NAC} 5 \mathrm{mM}$

G1 phase $\quad 56.8 \%$

Sphase $\quad 15.9 \%$

G2-M phase $14.9 \%$

C. HCT116
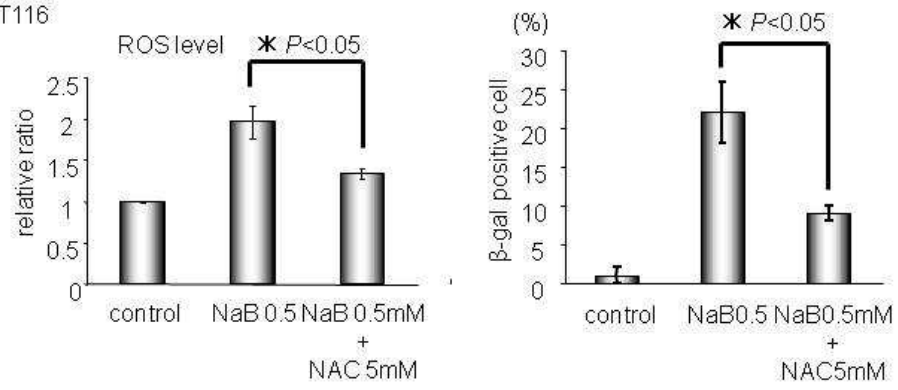

Fig. 4. Enhancement of ROS levels in cancer cell lines in response to NaB.

(a) ROS levels were evaluated by FACS analysis after staining HCT116 cells with the fluorescent probe APF. The ROS levels in apoptotic cells treated with $1.0 \mathrm{mM} \mathrm{NaB}$ are significantly higher than those in senescent cells induced by $5.0 \mathrm{mM} \mathrm{NaB}(P<0.05)$. 
Data represent the average of three independent experiments and standards deviations are indicated by error bars.

(b) Treatment of NAC reduced the proportion of cells accumulating in G2/M phase and the ratio of senescent cells following $\mathrm{NaB}$ treatment. HCT116 cells were cultured with $0.5 \mathrm{mM}$ $\mathrm{NaB}$ in the presence or absence of $0.5 \mathrm{mM}$ NAC for $24 \mathrm{hrs}$.

(c) ROS level (left graph) and the ratio of senescent cells (right graph) after 96 hrs of treatment significantly decreased in the presence of NAC $(P<0.05)$ compared to when NAC was absent. Results represent the mean values of three experiments, and error bars shows the standard deviation.

A

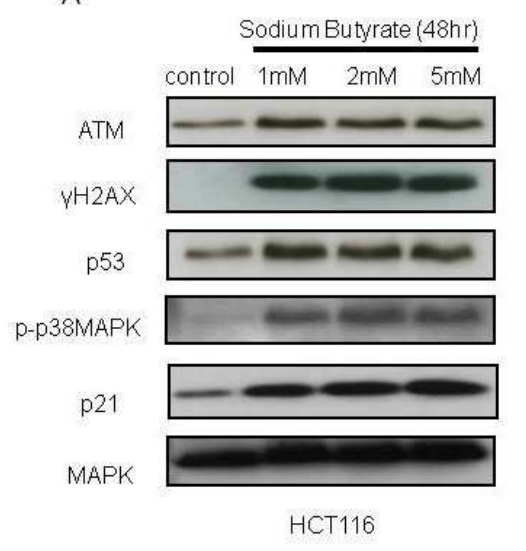

B

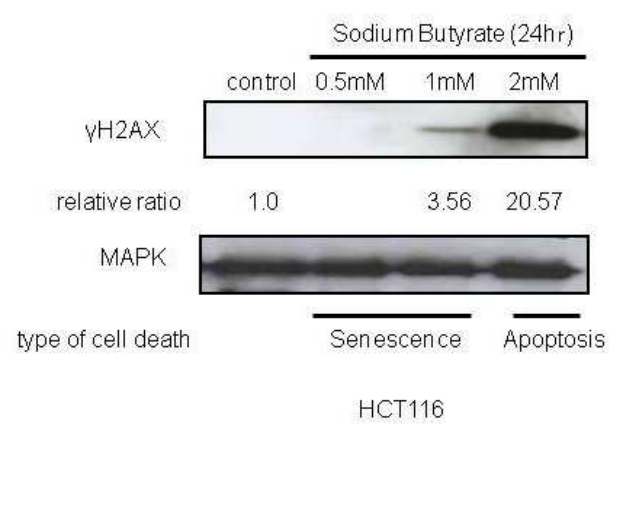

Fig. 5. NaB induced the expression of proteins associated with DSB.

(a) Western blot of ATM, phosphorylated H2AX ( $\gamma \mathrm{H} 2 \mathrm{AX}$ ), p53, phosphorylated p38 MAPK, p21 and MAPK after treatment with $\mathrm{NaB}$ treatment for $48 \mathrm{hrs}$.

(b) The level of $\gamma \mathrm{H} 2 \mathrm{AX}$ protein in cells treated with $2.0 \mathrm{mM} \mathrm{NaB}$ for $24 \mathrm{hrs}$, was higher than that in cells treated with $1.0 \mathrm{mM} \mathrm{NaB}$, a level which induced senescence. Levels of $\gamma \mathrm{H} 2 \mathrm{AX}$ associated with the type determination of cell death.

\section{Conclusion}

In this study, we obtained the following evidence. Exogenous and endogenous p21 upregulation (Ad-p21 infection and $\mathrm{NaB}$ treatment) are able to induce senescence or apoptosis in cancer cell lines. The magnitude of ROS induced by p21 was critical for the p21-mediated cell fate decision. These findings help account for the differences in the p21-mediated cell fate decisions observed in various studies.

\section{References}

Chen QM, Bartholomew JC, Campisi J, Acosta M, Reagan JD, and Ames BN. Molecular analysis of $\mathrm{H} 2 \mathrm{O} 2$-induced senescent-like growth arrest in normal human fibroblasts: p53 and Rb control G1 arrest but not cell replication. Biochem J 1998; 332: 43-50 
Di Leonardo A, Linke SP, Clarkin K, and Wahl GM. DNA damage triggers a prolonged p53dependent G1 arrest and long-term induction of Cip1 in normal fibroblasts. Genes Dev 1994; 8: 2540-51

Dumont P. Burton M, Chen QM, Gonos ES, Frippiat C, Mazarati J, Eliaers F, Remacle J, and Toussaint $\mathrm{O}$. Induction of replicative senescence biomarkers by sublethal oxidative stress in normal human fibroblast. Free Radical Biol Med 2000; 28: 361-73

Deng C, Zhang P, Harper JW, Elledge SJ, and Leder P. Mice lacking p21CIP1/WAF1 undergoes normal development, but is defective in G1 checkpoint control. Cell 1995; 82: 675-84

Hsu SL, Chen MC, Chou YH, Hwang GY, and Yin SC. Induction of p21(CIP1/Waf1) and activation of p34(cdc2) involved in retinoic acid-induced apoptosis in human hepatoma Hep3B cells. Exp Cell Res 1999; 248: 87-96

Hagen TM, Yowe DL, Bartholomew JC, Wehr CM, Do KL, Park JY, and Ames BN. Mitochondria decay in hepatocytes from old rats: membrane potential declines, heterogeneity and oxidants increase. Proc Natl Acad Sci U S A 1997; 94: 3064-69

Kagawa S, Fujiwara T, Kadowaki Y, Fukazawa T, Sok-Joo R, Jack A, Roth JA, and Tanaka N. Overexpression of the p21 ${ }^{\text {sdil }}$ gene induces senescence-like state in human cancer cells: implication for senescence-directed molecular therapy for cancer. Cell Death and Differentiation 1999; 6: 765-772

Lee AC, Fenster BE, Ito H, Takeda K, Bae NS, Hirai T, Yu ZX, Ferrans VJ, Howard BH, and Finkel T. Ras protein induce senescence by altering the intracellular levels of reactive oxygen spiecies. J Biol Chem 1999; 274: 7936-40

Macip S, Igarshi M, Berggren P, Yu J, Lee SW, and Aaroson SA. Influence of induced reactive oxygen species in p53-mediated cell gate decisions. Mol Cell Biol 2003; 23: 8576-85

Macip S, Igarshi M, Fang L, Chen A, Pan ZO, Lee SW, and Aaroson S. Inhibirion of p21mediated ROS accumulation can rescue p21-induced senescence. EMBO J 2002; 21: 2180-88

Orr WC, and Sohal RS. Extension of life-span by overexpression of superoxide dismutase and catalase in Drosophila melanogaster. Science 1994; 263: 1128-30

Polyak K, Xia Y, Zweier JL, Kinzler KW, and Vogelstein B. A model for p53-induced apoptosis. Nature 1997; 389: 300-305

Roninson I. Tumor Cell Senescence in Cancer Treatment. Cancer Research 2003;63:2705-15

Redon C, Pilch D, Rogakou E, Sedelnikova O, Newrock K, Bonner W. Histone H2A variants H2AX and H2AZ. Curr Opin Genet Dev 2002; 12: 162-9

Setsukinai K, Urano Y, Kakinuma K, Majima HJ, Nagano T. Development of novel fluorescence probes that can reliably detect reactive oxygen species and distinguish specific species. J Biol Chem 2003; 278: 3170-75

Tsao Y, Huang S, Chang J, Hsieh J, Pong R, and Chen S. Adenovirus-mediated p21(WAF1/SDII/CIP1) gene transfer induces apoptosis of human cervical cancer cell lines. Journal of Virology 1999; 6: 4849-90

Vaziri H, West MD, Allsopp RC, Davison TS, Wu YS, Arrowsmith CH, Poirier GG., and Benchimol S. ATM-depenent telomere loss in aging human diploid fibroblasts and DNA damage lead to the posttranslational activation of p53 protein involving poly (ADP-ribose) polymerase. EMBO J 1997; 16: 6018-33 
von Zglinicki, T. Telomeres and replicative senescence: Is it only length that counts? Cancer Lett 2001; 168: 111-6

Waldman T, Lengauer C, Kinzlar KW, and Vogelstein B. Uncoupling of S phase and mitosis induced by anticancer agent in cells lacking p21. Nature 1996;381:713-6 


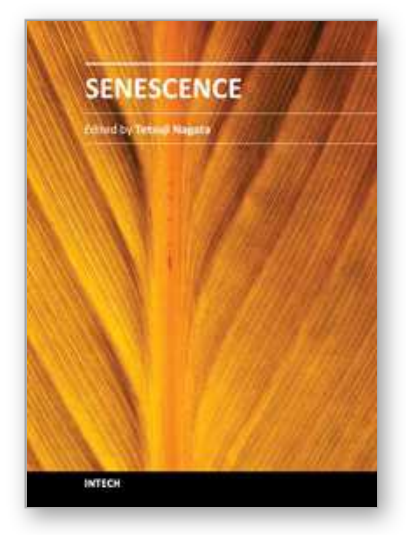

\author{
Senescence \\ Edited by Dr. Tetsuji Nagata
}

ISBN 978-953-51-0144-4

Hard cover, 850 pages

Publisher InTech

Published online 29, February, 2012

Published in print edition February, 2012

The book "Senescence" is aimed to describe all the phenomena related to aging and senescence of all forms of life on Earth, i.e. plants, animals and the human beings. The book contains 36 carefully reviewed chapters written by different authors, aiming to describe the aging and senescent changes of living creatures, i.e. plants and animals.

\title{
How to reference
}

In order to correctly reference this scholarly work, feel free to copy and paste the following:

Takafumi Inoue and Norio Wake (2012). The Level of ROS and DNA Damage Mediate with the Type of Cell Death, Senescence or Apoptosis, Senescence, Dr. Tetsuji Nagata (Ed.), ISBN: 978-953-51-0144-4, InTech, Available from: http://www.intechopen.com/books/senescence/the-level-of-ros-and-dna-damage-mediate-withthe-type-of-cell-death-senescence-or-apoptosis

\section{INTECH}

open science | open minds

\author{
InTech Europe \\ University Campus STeP Ri \\ Slavka Krautzeka 83/A \\ 51000 Rijeka, Croatia \\ Phone: +385 (51) 770447 \\ Fax: +385 (51) 686166 \\ www.intechopen.com
}

\author{
InTech China \\ Unit 405, Office Block, Hotel Equatorial Shanghai \\ No.65, Yan An Road (West), Shanghai, 200040, China \\ 中国上海市延安西路65号上海国际贵都大饭店办公楼405单元 \\ Phone: +86-21-62489820 \\ Fax: $+86-21-62489821$
}


(C) 2012 The Author(s). Licensee IntechOpen. This is an open access article distributed under the terms of the Creative Commons Attribution 3.0 License, which permits unrestricted use, distribution, and reproduction in any medium, provided the original work is properly cited. 